\title{
Luminal $\mathrm{Ca}^{2+}$ regulates passive $\mathrm{Ca}^{2+}$ efflux from the intracellular stores of hepatocytes
}

\author{
Mike D. BEECROFT and Colin W. TAYLOR ${ }^{1}$ \\ Department of Pharmacology, University of Cambridge, Tennis Court Road, Cambridge CB2 1QJ, U.K.
}

$\mathrm{Ca}^{2+}$ uptake into the intracellular stores of permeabilized hepatocytes was entirely dependent on ATP and substantially inhibited by either ionomycin or thapsigargin, although both were required for complete inhibition. Unidirectional efflux of ${ }^{45} \mathrm{Ca}^{2+}$ after removal of ATP from cells loaded to steady state $\left(1.60 \pm 0.12 \mathrm{nmol} / 10^{6}\right.$ cells) was monoexponential and occurred with a half-time of $103 \pm 10 \mathrm{~s}$. However, the ${ }^{45} \mathrm{Ca}^{2+}$ content of the stores did not return to their pre-ATP level, but reached a plateau at $0.12 \pm 0.04 \mathrm{nmol} / 10^{6}$ cells. A similar amount of $\mathrm{Ca}^{2+}$ was trapped within the stores when $\mathrm{Ca}^{2+}$ uptake was prevented by thapsigargin and chelation of $\mathrm{Ca}^{2+}$; at all temperatures between $2{ }^{\circ} \mathrm{C}$ and $37^{\circ} \mathrm{C}$; and after stores had first been loaded with unlabelled $\mathrm{Ca}^{2+}$. Simultaneous addition of inositol 1,4,5trisphosphate $\left(\operatorname{Ins} P_{3}\right)$ and inhibition of $\mathrm{Ca}^{2+}$ uptake reduced the amount of trapped $\mathrm{Ca}^{2+}$ to a level consistent with $\operatorname{Ins} P_{3}$ rapidly and more completely emptying a fraction of the stores that could be only partially emptied by the passive leak. After dilution of the specific activity of the ${ }^{45} \mathrm{Ca}^{2+}$ under conditions that maintained the steady-state activities of the pumps and leaks, the stores rapidly lost their entire ${ }^{45} \mathrm{Ca}^{2+}$ content. We conclude that the channel responsible for mediating the leak of $\mathrm{Ca}^{2+}$ abruptly closes when the luminal $\left[\mathrm{Ca}^{2+}\right]$ of the intracellular stores falls below a critical threshold corresponding to about $7 \%$ of their steady-state loading. Whereas $\operatorname{Ins} P_{3}$ is capable of completely emptying a fraction of the stores, regulation of the passive leak by luminal $\left[\mathrm{Ca}^{2+}\right]$ is likely to prevent it from completely emptying them; such regulation may ensure that the many other functions of $\mathrm{Ca}^{2+}$ within the endoplasmic reticulum are not compromised.

\section{INTRODUCTION}

The initial response of many cells to stimuli that evoke an increase in cytosolic $\left[\mathrm{Ca}^{2+}\right]$ results from mobilization of intracellular $\mathrm{Ca}^{2+}$ stores [1]. The $\mathrm{Ca}^{2+}$ stores are also important in mediating the subsequent influx of $\mathrm{Ca}^{2+}$ across the plasma membrane, because it is the capacitative $\mathrm{Ca}^{2+}$ entry pathway, activated by depletion of the stores, that is commonly responsible for the $\mathrm{Ca}^{2+}$ entry evoked by receptors linked to $\operatorname{Ins} P_{3}$ formation [2,3]. The involvement of $\mathrm{Ca}^{2+}$ stores in both phases of the response evoked by $\mathrm{Ca}^{2+}$-mobilizing stimuli, and the demonstration that $\mathrm{Ca}^{2+}$ waves and spikes usually reflect the periodic mobilization and reuptake of $\mathrm{Ca}^{2+}$ from intracellular stores [4], has focused attention on the role of inositol 1,4,5-trisphosphate $\left(\operatorname{Ins} P_{3}\right)$ and its receptors in mediating the effects of hormones on intracellular $\mathrm{Ca}^{2+}$ stores [5]. Even within single cells, the $\mathrm{Ca}^{2+}$ stores themselves, probably largely within the endoplasmic reticulum, are functionally heterogenous, with differing sensitivities to $\mathrm{Ca}^{2+}$-mobilizing messengers, different $\mathrm{Ca}^{2+}$-uptake mechanisms and different rates of $\mathrm{Ca}^{2+}$ leak [6-8]. The role of $\mathrm{Ca}^{2+}$ within the endoplasmic reticulum is not, however, restricted to $\mathrm{Ca}^{2+}$ signalling [9]: luminal $\mathrm{Ca}^{2+}$ is also implicated in protein folding and assembly [10] and in cell growth [11]. The $\mathrm{Ca}^{2+}$ content of the endoplasmic reticulum, reflecting the balance between $\mathrm{Ca}^{2+}$ leaks and active $\mathrm{Ca}^{2+}$ uptake, is therefore important in both allowing cells to respond to extracellular stimuli and in directly regulating various aspects of cell behaviour. Whereas the active $\mathrm{Ca}^{2+}$-uptake mechanisms, mediated largely by a family of $\mathrm{Ca}^{2+}$ pumps, the sarcoplasmic/ endoplasmic reticulum $\mathrm{Ca}^{2+}$-ATPases (SERCAs) [8], have been characterized extensively, the means whereby $\mathrm{Ca}^{2+}$ leaks from the endoplasmic reticulum under basal conditions is poorly understood. In the present study, we have examined the basal $\mathrm{Ca}^{2+}$ leak from the intracellular stores of permeabilized hepatocytes and suggest that it is mediated by a channel that abruptly closes as the luminal free $\left[\mathrm{Ca}^{2+}\right]$ falls below a critical level. This form of regulation may serve to protect cells from the potentially damaging effects of completely emptying the endoplasmic reticulum of $\mathrm{Ca}^{2+}[9]$.

\section{MATERIALS AND METHODS}

\section{Materials}

Ins $P_{3}$ was from American Radiolabeled Chemicals (St. Louis, MO, U.S.A.), ${ }^{45} \mathrm{CaCl}_{2}$ was from ICN (Thame, Oxon, U.K.) and thapsigargin was from Alamone Laboratories (Jerusalem, Israel). Apyrase (from potato) and hexokinase (type V from baker's yeast) were from Sigma (St. Louis, MO, U.S.A.). All other reagents were from suppliers reported previously [12].

\section{Measurement of ${ }^{45} \mathrm{Ca}^{2+}$ efflux}

Hepatocytes were isolated from livers of male Wistar rats [13] and then permeabilized by incubation with saponin $(10 \mu \mathrm{g} / \mathrm{ml})$ in cytosol-like medium (CLM) containing $140 \mathrm{mM} \mathrm{KCl}, 20 \mathrm{mM}$ $\mathrm{NaCl}, 2 \mathrm{mM} \mathrm{MgCl}$, $1 \mathrm{mM}$ EGTA, $20 \mathrm{mM}$ Pipes (pH 7 at $\left.37^{\circ} \mathrm{C}\right)$. The cells were washed and resuspended $\left(10^{7}\right.$ cells $\left./ \mathrm{ml}\right)$ in CLM supplemented with $\mathrm{CaCl}_{2}$ (free $\left.\left[\mathrm{Ca}^{2+}\right]=200 \mathrm{nM}\right)$, ATP (7.5 mM), carbonyl cyanide $p$-trifluoromethoxyphenylhydrazone

Abbreviations used: CLM, cytosol-like medium; $\mathrm{EC}_{50}$, half-maximally effective concentration; Ins $P_{3}$, inositol 1,4,5-trisphosphate; SERCA, sarcoplasmic/endoplasmic reticulum $\mathrm{Ca}^{2+}$-ATPase; $t_{1 / 2}$, half-time; FCCP, carbonyl cyanide $p$-trifluoromethoxyphenylhydrazone.

${ }^{1}$ To whom correspondence should be addressed (e-mail cwt1000@cam.ac.uk) 


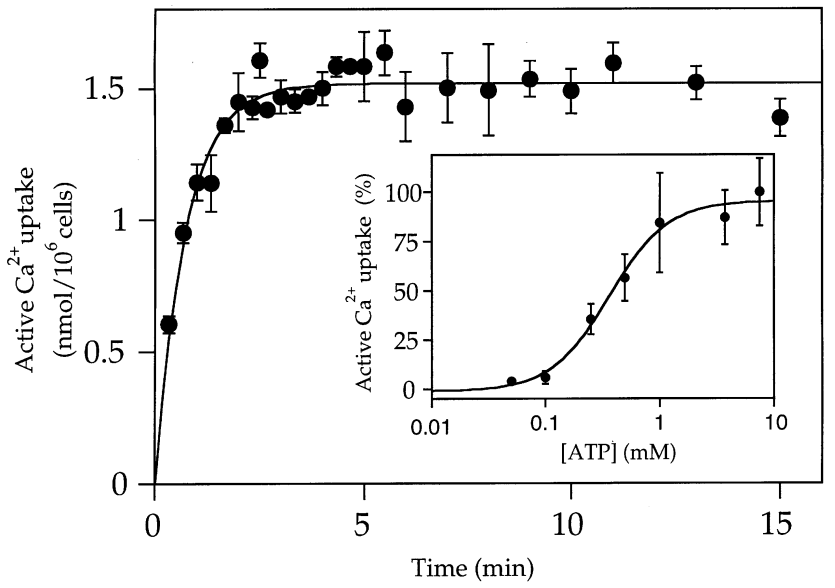

Figure 1 Effects of ATP, ionomycin and thapsigargin on ${ }^{45} \mathrm{Ca}^{2+}$ uptake by the intracellular stores of permeabilized hepatocytes

Permeabilized hepatocytes were incubated in CLM containing $7.5 \mathrm{mM}$ ATP for the periods shown, and their ${ }^{45} \mathrm{Ca}^{2+}$ contents expressed as that which could be released by addition of ionomycin $(5 \mu \mathrm{M})$ and thapsigargin $(1 \mu \mathrm{M})$. Results are means \pm S.E.M. of 5 independent experiments. The inset shows the effects of varying the ATP concentration on the ${ }^{45} \mathrm{Ca}^{2+}$ uptake measured $5 \mathrm{~min}$ after its addition. Results (\% of uptake observed with $7.5 \mathrm{mM}$ ATP) are means \pm S.E.M. of 3-9 independent experiments.

(FCCP, $10 \mu \mathrm{M}$ ) and ${ }^{45} \mathrm{Ca}^{2+}(7.5 \mu \mathrm{Ci} / \mathrm{ml})$. After $5 \mathrm{~min}$, the stores had loaded to steady state with ${ }^{45} \mathrm{Ca}^{2+}$ (Figure 1). To allow rapid enzymic removal of ATP in some experiments, the concentration of ATP was reduced to $1.5 \mathrm{mM}$; this reduction had no effect on the steady-state $\mathrm{Ca}^{2+}$ content of the cells (Figure 1). Unidirectional efflux of ${ }^{45} \mathrm{Ca}^{2+}$ from the loaded stores was examined after rapid inhibition of further $\mathrm{Ca}^{2+}$ uptake using the methods described in the Results and discussion section. At intervals thereafter, the ${ }^{45} \mathrm{Ca}^{2+}$ contents of the stores were determined by quenching the incubations with ice-cold medium containing sucrose $(310 \mathrm{mM})$ and trisodium citrate $(1 \mathrm{mM})$, and then rapidly filtering them through Whatman GF/C filters [13].

In order to measure unidirectional ${ }^{45} \mathrm{Ca}^{2+}$ efflux from stores that retained their steady-state $\mathrm{Ca}^{2+}$ content, permeabilized cells loaded with ${ }^{45} \mathrm{Ca}^{2+}$ were diluted fivefold into CLM containing $20 \mathrm{mM}$ EGTA and sufficient $\mathrm{CaCl}_{2}$ to maintain the free $\left[\mathrm{Ca}^{2+}\right]$ at $200 \mathrm{nM}$. This method allowed a 100 -fold dilution of the specific activity of the ${ }^{45} \mathrm{Ca}^{2+}$ while otherwise preserving the composition of the CLM. The non-specific binding of ${ }^{45} \mathrm{Ca}^{2+}$ to permeabilized cells attained its final level within $20 \mathrm{~s}$ of changing either the free $\left[\mathrm{Ca}^{2+}\right]$ or specific activity of the medium (results not shown); actively accumulated ${ }^{45} \mathrm{Ca}^{2+}$ was therefore calculated using different determinations of non-specific binding before and after the medium change (see Figure 3, below). For reasons described in the Results and discussion section, active ${ }^{45} \mathrm{Ca}^{2+}$ uptake by the intracellular stores was defined as that which was inhibited by the combination of ionomycin $(5 \mu \mathrm{M})$ and thapsigargin $(1 \mu \mathrm{M})$.

Computer-assisted curve-fitting (Kaleidagraph) was used to fit exponential equations. For statistical analyses requiring comparison of ratios of two observations, S.E.M. values were determined according to [14].

\section{RESULTS AND DISCUSSION}

\section{ATP-dependent $\mathrm{Ca}^{2+}$ uptake by intracellular stores}

Addition of ATP to permeabilized hepatocytes stimulated ${ }^{45} \mathrm{Ca}^{2+}$ accumulation by the intracellular stores: the half-time $\left(t_{1 / 2}\right)$ for
Table 1 Effects of ionomycin and thapsigargin on ATP-dependent ${ }^{45} \mathrm{Ca}^{2+}$ uptake

Permeabilized hepatocytes were incubated for $5 \mathrm{~min}$ in CLM with the indicated additions of ionomycin $(5 \mu \mathrm{M})$, thapsigargin $(1 \mu \mathrm{M})$, ATP $(7.5 \mathrm{mM})$ or GTP $(7.5 \mathrm{mM})$. Both the total amount of ${ }^{45} \mathrm{Ca}^{2+}$ associated with the cells and the active ${ }^{45} \mathrm{Ca}^{2+}$ uptake (that which was prevented by ionomycin and thapsigargin) are shown as means \pm S.E.M. of $n$ independent experiments (shown in parentheses).

\begin{tabular}{lll}
\hline & $\begin{array}{l}\text { Total }{ }^{45} \mathrm{Ca}^{2+} \text { content } \\
\left(\mathrm{nmol} / 10^{6} \mathrm{cells}\right)\end{array}$ & $\begin{array}{l}\text { Active }{ }^{45} \mathrm{Ca}^{2+} \text { uptake } \\
\left(\mathrm{nmol} / 10^{6} \mathrm{cells}\right)\end{array}$ \\
\hline No additions & $0.21 \pm 0.01(54)$ & - \\
ATP & $1.90 \pm 0.1(30)$ & $1.60 \pm 0.20$ \\
ATP + ionomycin & $0.54 \pm 0.03(29)$ & $0.24 \pm 0.03$ \\
ATP + thapsigargin & $0.40 \pm 0.02(30)$ & $0.10 \pm 0.01$ \\
ATP + thapsigargin + ionomycin & $0.30 \pm 0.02(23)$ & 0 \\
Thapsigargin + ionomycin & $0.18 \pm 0.02(4)$ & - \\
GTP + thapsigargin + ionomycin & $0.34 \pm 0.04(3)$ & - \\
& &
\end{tabular}

loading was $46 \pm 3 \mathrm{~s}(n=23)$ and, under the conditions used for our experiments, the half-maximal effect $\left(\mathrm{EC}_{50}\right)$ of ATP occurred when its concentration was $360 \mu \mathrm{M}$ (Figure 1). In the absence of ATP, the ${ }^{45} \mathrm{Ca}^{2+}$ content of permeabilized hepatocytes was the same after $20 \mathrm{~s}$ and $10 \mathrm{~min}$ (results not shown), and was unaffected by thapsigargin $(1 \mu \mathrm{M})$ or ionomycin $(5 \mu \mathrm{M})$ (Table 1). In the presence of ATP, ionomycin and thapsigargin ${ }^{45} \mathrm{Ca}^{2+}$ uptake was reduced to the non-specific ${ }^{45} \mathrm{Ca}^{2+}$ binding observed when GTP replaced ATP (Table 1). We conclude that all ${ }^{45} \mathrm{Ca}^{2+}$ uptake into the intracellular stores is ATP dependent.

Either thapsigargin $(1 \mu \mathrm{M})$ or ionomycin $(5 \mu \mathrm{M})$ substantially attenuated ATP-dependent ${ }^{45} \mathrm{Ca}^{2+}$ uptake, but neither alone entirely prevented it (Table 1 ): $\approx 6 \%$ and $\approx 15 \%$ of the active ${ }^{45} \mathrm{Ca}^{2+}$ uptake persisted in the presence of thapisgargin and ionomycin, respectively. These results indicate that even in the presence of FCCP, a protonophore, ATP stimulates $\mathrm{Ca}^{2+}$ uptake into stores, some of which are resistant to ionomycin and some to thapsigargin. The latter may reflect the existence of a thapsigargin-insensitive $\mathrm{Ca}^{2+}$-uptake mechanism [7,8]. Alternatively, since thapsigargin completely inhibits the SERCA only after addition of ATP allows it to complete its catalytic cycle [15], the small amount of ${ }^{45} \mathrm{Ca}^{2+}$ uptake $(\approx 6 \%$ of active uptake) that persisted in the presence of thapsigargin may result from $\mathrm{Ca}^{2+}$ accumulated before inhibition was complete becoming trapped within the stores (see below). We have no simple explanation for the $\mathrm{Ca}^{2+}$ uptake $(\approx 15 \%$ of active uptake) that persisted in the presence of ionomycin; it is unlikely to reflect the behaviour of an acidic pool [16], because FCCP was present throughout. The important point is that in all subsequent experiments, we focused exclusively on the stores that were sensitive to both thapsigargin and ionomycin, and defined active ${ }^{45} \mathrm{Ca}^{2+}$ sequestration as that released by the combination of both inhibitors (see the Materials and methods section).

\section{Incomplete emptying of intracellular $\mathrm{Ca}^{2+}$ stores after inhibition of $\mathrm{Ca}^{2+}$ uptake}

Addition of apyrase (50 units/ml), glucose $(10 \mathrm{mM})$ and hexokinase (50 units $/ \mathrm{ml}$ ) to CLM to hydrolyse the ATP before addition of the permeabilized cells prevented active ${ }^{45} \mathrm{Ca}^{2+}$ uptake, confirming that the enzyme mixture reduced the ATP level to below that required to support ${ }^{45} \mathrm{Ca}^{2+}$ accumulation (Figure 2). Pre-incubation with glucose and hexokinase alone did not fully prevent active $\mathrm{Ca}^{2+}$ uptake, even when their respective concentrations were increased to $20 \mathrm{mM}$ and 75 units/ml. Addition of 


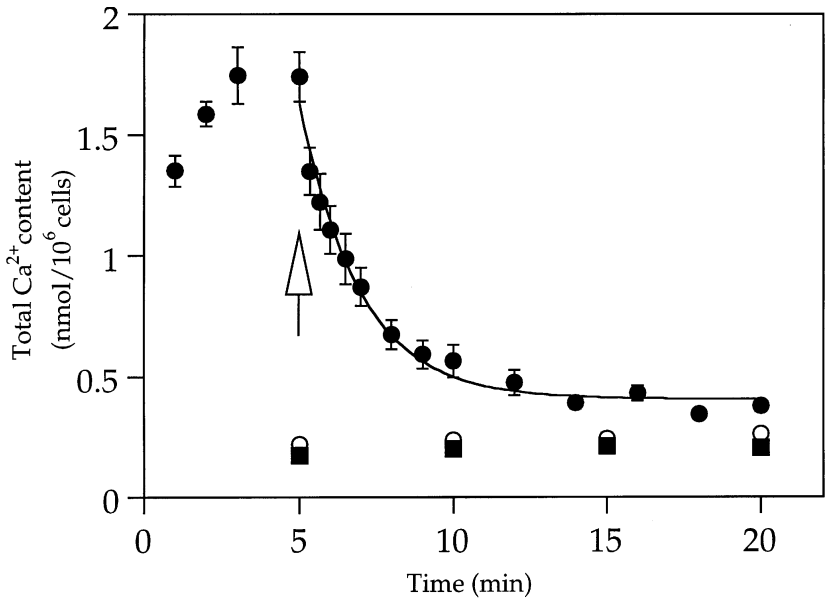

Figure 2 Incomplete loss of actively accumulated ${ }^{45} \mathrm{Ca}^{2+}$ afer removal of ATP from permeabilized cells

Permeabilized cells were loaded to steady state $(5 \mathrm{~min})$ with ${ }^{45} \mathrm{Ca}^{2+}$, and ATP $(1.5 \mathrm{mM})$ was then rapidly removed by addition of the hexokinase/apyrase/glucose mixture (arrow; see the Results and discussion section). The subsequent decline in the actively accumulated ${ }^{45} \mathrm{Ca}^{2+}$ content of the cells $(\mathbf{O})$ was fitted to a monoexponential equation. In parallel experiments, ATP was omitted $(\boldsymbol{\square})$ or removed by the enzyme mixture before addition of the cells $(O)$. Results are means \pm S.E.M. of 6 independent experiments (most error bars are smaller than the symbols)

the full enzyme mixture to cells loaded to steady state with ${ }^{45} \mathrm{Ca}^{2+}$ in the presence of ATP $(1.5 \mathrm{mM})$ caused their $\mathrm{Ca}^{2+}$ content to monoexponentially decline $\left(t_{1 / 2}=103 \pm 10 \mathrm{~s}, n=6\right)$ to a level $\left(0.12 \pm 0.04 \mathrm{nmol} / 10^{6}\right.$ cells $)$ that remained elevated above that recorded in cells that had not been incubated with ATP (Figure 2). This incomplete emptying of the $\mathrm{Ca}^{2+}$ stores occurred despite recording ${ }^{45} \mathrm{Ca}^{2+}$ efflux over an interval $(15 \mathrm{~min})$ corresponding to almost 9 half-times, during which we would have expected the ${ }^{45} \mathrm{Ca}^{2+}$ content of the stores to fall to $\approx 0.2 \%$ of their final level (Figure 2). Increasing the period during which the stores were allowed to actively load with ${ }^{45} \mathrm{Ca}^{2+}$ had no effect on their steadystate $\mathrm{Ca}^{2+}$ content, which in parallel experiments was $2.58 \pm$ $0.09 \mathrm{nmol} / 10^{6}$ cells $(n=6)$ after $5 \mathrm{~min}, 2.57 \pm 0.06 \mathrm{nmol} /$ $10^{6}$ cells after $10 \mathrm{~min}$, and $2.30 \pm 0.15 \mathrm{nmol} / 10^{6}$ cells after $15 \mathrm{~min}$. Furthermore, the residual $\mathrm{Ca}^{2+}$ content was similar whether stores had first been allowed to load to steady state for $5 \mathrm{~min}$ (residual content $=0.14 \pm 0.1 \mathrm{nmol} / 10^{6}$ cells $), 10 \mathrm{~min}(0.17 \pm$ $0.01 \mathrm{nmol} / 10^{6}$ cells $)$, or $15 \mathrm{~min}\left(0.16 \pm 0.02 \mathrm{nmol} / 10^{6}\right.$ cells $)$, indicating that it did not result from $\mathrm{Ca}^{2+}$ slowly accumulating within a store. These results suggest that $\approx 7 \%$ of the ${ }^{45} \mathrm{Ca}^{2+}$ that was rapidly accumulated in response to addition of ATP was not readily released from the stores when ATP was subsequently removed. Similar results were obtained when further ${ }^{45} \mathrm{Ca}^{2+}$ uptake into the stores was inhibited by addition of thapsigargin $(1 \mu \mathrm{M})$ with or without simultaneous fivefold dilution of the cells into medium containing EGTA (final, $8 \mathrm{mM}$ ) to reduce the free $\left[\mathrm{Ca}^{2+}\right]$ to $\approx 3 \mathrm{nM}$ (Table 2 ). The latter results confirm that $\mathrm{Ca}^{2+}$ trapped within stores after ATP removal is not a consequence of compartmentalization of ATP [17]. We conclude that all $\mathrm{Ca}^{2+}$ uptake by the intracellular stores is ATP-dependent, but a fraction of that $\mathrm{Ca}^{2+}$ cannot be released when further $\mathrm{Ca}^{2+}$ uptake is prevented.

We were concerned that fragmentation of the endoplasmic reticulum during permeabilization [18] might have created a $\mathrm{Ca}^{2+}$ pool lacking the pathway through which $\mathrm{Ca}^{2+}$ leaks, or that a very high affinity $\mathrm{Ca}^{2+}$-binding site within the stores might lose
Table 2 Incomplete emptying of the stores after inhibition of ${ }^{45} \mathrm{Ca}^{2+}$ uptake

Permeabilized hepatocytes were loaded to steady state with ${ }^{45} \mathrm{Ca}^{2+}$ and further ${ }^{45} \mathrm{Ca}^{2+}$ uptake was then prevented by addition of thapsigargin $(1 \mu \mathrm{M})$, removal of ATP $(1.5 \mathrm{mM})$ using apyrase/glucose/hexokinase, or by addition of thapsigargin $(1 \mu \mathrm{M})$ and chelation of $\mathrm{Ca}^{2+}$. In the final experiment, the cells were loaded to steady state with unlabelled $\mathrm{Ca}^{2+}$ before loading with ${ }^{45} \mathrm{Ca}^{2+}$, and then further $\mathrm{Ca}^{2+}$ uptake was prevented by addition of thapsigargin and chelation of $\mathrm{Ca}^{2+}$. The ${ }^{45} \mathrm{Ca}^{2+}$ contents of the cells were measured at intervals over the next $15 \mathrm{~min}$, and the resulting unidirectional ${ }^{45} \mathrm{Ca}^{2+}$ efflux curves were fitted to monoexponential equations from which the $t_{1 / 2}$ and residual $\mathrm{Ca}^{2+}$ contents at infinite time were calculated. Results are means \pm S.E.M. $n$ independent experiments (shown in parentheses).

\begin{tabular}{lll}
\hline & & $\begin{array}{l}\text { Residual actively } \\
\text { accumulated }\end{array}$ \\
& $t_{1 / 2}(\mathrm{~s})$ & ${ }^{45} \mathrm{Ca}^{2+}\left(\mathrm{nmol} / 10^{6}\right.$ cells $)$ \\
\hline $\begin{array}{l}\text { Apyrase/glucose/hexokinase (6) } \\
\text { Thapsigargin and chelation of } \mathrm{Ca}^{2+}(5)\end{array}$ & $103 \pm 10$ & $0.12 \pm 0.04$ \\
$\begin{array}{l}\text { Thapsigargin alone }(10) \\
\text { Thapsigargin and chelation of } \mathrm{Ca}^{2+} \text { after } \\
\text { pre-loading with }{ }^{40} \mathrm{Ca}^{2+}(6)\end{array}$ & $119 \pm 6$ & $0.10 \pm 0.03$ \\
& $121 \pm 18$ & $0.11 \pm 0.02$ \\
& & \\
\hline
\end{tabular}

its $\mathrm{Ca}^{2+}$ during the permeabilization protocol and then avidly bind the first $\mathrm{Ca}^{2+}$ to be transported into the stores. These possibilities were discounted by the results from two further series of experiments.

The amount of $\mathrm{Ca}^{2+}$ actively accumulated by the intracellular stores at steady state was similar whether the cells were loaded for $5 \mathrm{~min}$ in CLM containing ${ }^{45} \mathrm{Ca}^{2+}\left(1.15 \pm 0.09 \mathrm{nmol} / 10^{6}\right.$ cells, $n=3$ ) or first allowed to load (5 min) with unlabelled $\mathrm{Ca}^{2+}$ and then loaded for a further 5 min with ${ }^{45} \mathrm{Ca}^{2+}\left(1.15 \pm 0.11 \mathrm{nmol} / 10^{6}\right.$ cells, $n=3$ ). In the stores preloaded with unlabelled $\mathrm{Ca}^{2+}$, both the kinetics of unidirectional ${ }^{45} \mathrm{Ca}^{2+}$ efflux and the residual $\mathrm{Ca}^{2+}$ remaining within the stores were similar to the values determined without preloading, but using the same method to inhibit $\mathrm{Ca}^{2+}$ uptake (Table 2). We conclude that a fraction of the $\mathrm{Ca}^{2+}$ actively accumulated into intracellular stores becomes trapped within them as their $\mathrm{Ca}^{2+}$ content falls, and that the trapped $\mathrm{Ca}^{2+}$ is not simply bound to slowly exchanging sites within the stores.

To measure ${ }^{45} \mathrm{Ca}^{2+}$ efflux from stores that remained loaded with $\mathrm{Ca}^{2+}$, permeabilized cells were loaded to steady state with ${ }^{45} \mathrm{Ca}^{2+}$, the specific activity of the ${ }^{45} \mathrm{Ca}^{2+}$ in the CLM was then diluted 100-fold while maintaining the composition of the CLM, including its free $\left[\mathrm{Ca}^{2+}\right]$ and ATP concentration (see the Materials and methods section). Under these conditions, the ${ }^{45} \mathrm{Ca}^{2+}$ content of the stores declined monoexponentially $\left(t_{1 / 2}=41 \pm 1 \mathrm{~s}, n=6\right)$ to a level corresponding to $1.1 \pm 0.4 \%$ of their steady-state loading (Figure 3). Since the specific activity of the CLM was reduced to $1 \%$ of its initial value, these results indicate that under steady-state conditions, all of the $\mathrm{Ca}^{2+}$ within the stores was rapidly exchangeable. We suggest that luminal $\mathrm{Ca}^{2+}$ regulates the rate at which $\mathrm{Ca}^{2+}$ leaks from the intracellular stores and that when the luminal $\left[\mathrm{Ca}^{2+}\right]$ falls below a critical threshold, the leak abruptly stops.

\section{The basal $\mathrm{Ca}^{2+}$ leak is through neither the $\operatorname{Ins} P_{3}$ receptor nor the $\mathrm{Ca}^{2+}$ pump}

Ins $P_{3}(10 \mu \mathrm{M}, 60 \mathrm{~s})$ rapidly released $41 \pm 3 \%(n=3)$ of the fully loaded $\mathrm{Ca}^{2+}$ stores, but in efflux experiments, addition of $\operatorname{Ins} P_{3}$ (10 $\mu \mathrm{M}, 60 \mathrm{~s})$ to cells that had essentially reached the residual $\mathrm{Ca}^{2+}$ content invariably failed to evoke $\mathrm{Ca}^{2+}$ release (results not shown). These results are consistent with previous reports in which stores substantially depleted of $\mathrm{Ca}^{2+}$ failed to respond to $\operatorname{Ins} P_{3}$ [19]. However, when $\operatorname{Ins} P_{3}(10 \mu \mathrm{M})$ was added at the same 


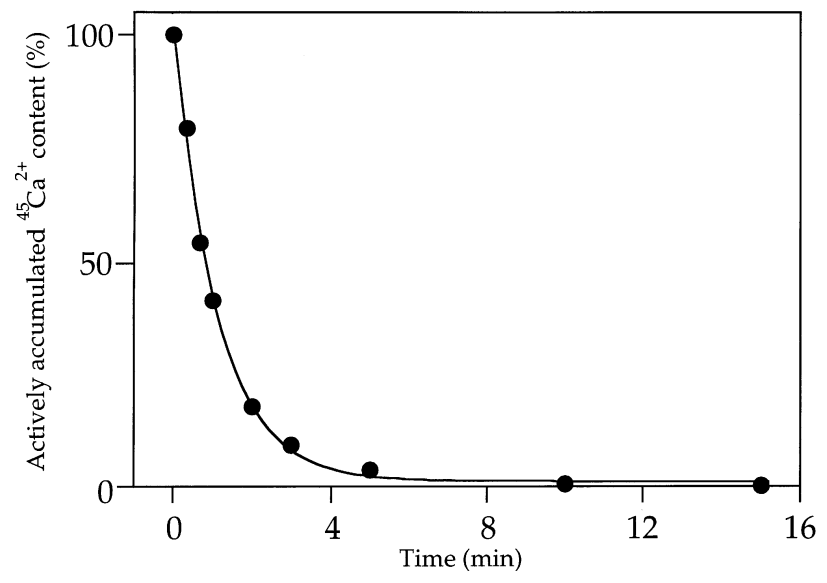

Figure 3 Effect of continued $\mathrm{Ca}^{2+}$ pumping on the ${ }^{45} \mathrm{Ca}^{2+}$ content of the stores

Cells loaded to steady state with ${ }^{45} \mathrm{Ca}^{2+}$ were diluted into CLM such that the specific activity of the ${ }^{45} \mathrm{Ca}^{2+}$ was reduced 100 -fold (see the Materials and methods section). The actively accumulated ${ }^{45} \mathrm{Ca}^{2+}$ content was determined at intervals, and the results (from a single experiment, typical of 6 independent experiments) fitted to a monoexponential equation.

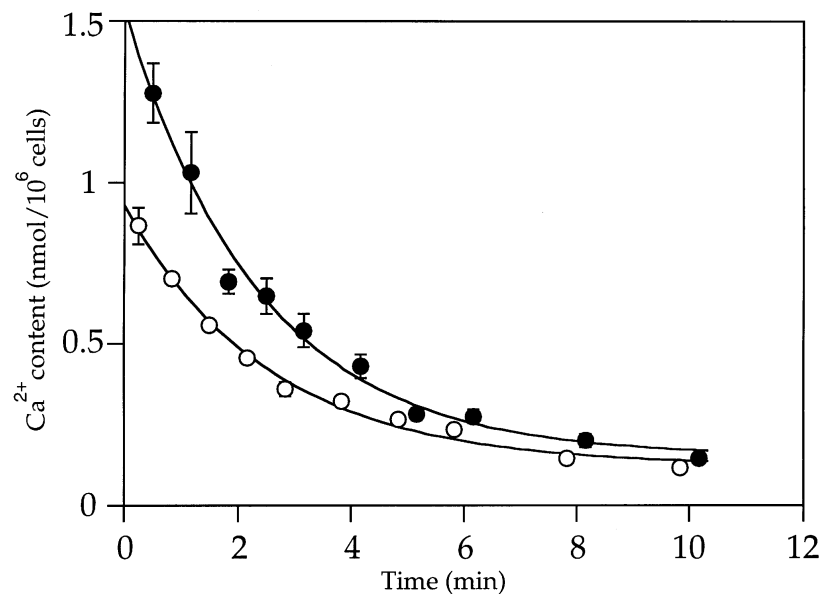

Figure 4 Passive leaks of ${ }^{45} \mathrm{Ca}^{2+}$ in the presence and absence of Ins $P_{3}$

Cells loaded to steady state with ${ }^{45} \mathrm{Ca}^{2+}$ were diluted into $\mathrm{Ca}^{2+}$-free $\mathrm{CLM}$ containing thapsigargin $(1 \mu \mathrm{M})$ in the presence $(O)$ or absence $(-)$ of Ins $P_{3}(10 \mu \mathrm{M})$ and the subsequent decline in the ${ }^{45} \mathrm{Ca}^{2+}$ contents of the cells was recorded (means \pm S.E.M. of 3 independent experiments). The lines were fitted to monoexponential equations and show that after the initial rapid release of $\mathrm{Ca}^{2+}$ by Ins $P_{3}$, passive $\mathrm{Ca}^{2+}$ efflux occurs at similar rates from unstimulated cells and those in which the $\operatorname{Ins} P_{3}$-sensitive stores had been completely emptied.

time as inhibition of further $\mathrm{Ca}^{2+}$ uptake, there was the expected rapid decrease in the $\mathrm{Ca}^{2+}$ content of the stores (by $34 \pm 1 \%$, $n=3$ ) and thereafter the rate of ${ }^{45} \mathrm{Ca}^{2+}$ efflux was similar in the presence $\left(t_{1 / 2}=108 \pm 13 \mathrm{~s}, n=3\right)$ or absence $\left(t_{1 / 2}=99 \pm 2 \mathrm{~s}, n=\right.$ 3 ) of Ins $P_{3}$ (Figure 4). In the cells treated with Ins $P_{3}$, the residual $\mathrm{Ca}^{2+}$ content of the stores was, however, reduced to $79 \pm 7 \%$ (n $=3$ ) of that of control cells. The results confirm [20] that $\mathrm{Ca}^{2+}$ leaks passively at similar rates from stores with and without Ins $P_{3}$ receptors, and that $\mathrm{Ca}^{2+}$ remains trapped within both $\operatorname{Ins} P_{3}$ sensitive and Ins $P_{3}$-insensitive stores. Therefore, in permeabilized hepatocytes, the basal $\mathrm{Ca}^{2+}$ leak is not mediated by $\operatorname{Ins} P_{3}$ receptors opening either spontaneously or in response to $\operatorname{Ins} P_{3}$. Whereas endogenous $\operatorname{Ins} P_{3}$ is unlikely to be sufficient to stimulate $\operatorname{Ins} P_{3}$
Table 3 Effects of temperature on ${ }^{45} \mathrm{Ca}^{2+}$ efflux from intracellular stores

${ }^{45} \mathrm{Ca}^{2+}$ efflux was measured at various temperatures after dilution of cells into $\mathrm{Ca}^{2+}$-free $\mathrm{CLM}$ containing thapsigargin $(1 \mu \mathrm{M})$. The $t_{1 / 2}$ and residual $\mathrm{Ca}^{2+}$ contents were determined from monoexponential curve fits derived from data spanning at least 6 half-times. Results are means \pm S.E.M. of $4-10$ independent determinations.

\begin{tabular}{cll}
\hline Temperature $\left({ }^{\circ} \mathrm{C}\right)$ & $t_{1 / 2}(\mathrm{~s})$ & $\begin{array}{l}\text { Residual }{ }^{45} \mathrm{Ca}^{2+} \\
\left(\mathrm{nmol} / 10^{6} \mathrm{cells}\right)\end{array}$ \\
\hline 2 & $589 \pm 54$ & $0.14 \pm 0.02$ \\
10 & $259 \pm 18$ & $0.19 \pm 0.02$ \\
20 & $208 \pm 9$ & $0.12 \pm 0.02$ \\
30 & $138 \pm 26$ & $0.10 \pm 0.02$ \\
37 & $111 \pm 8$ & $0.10 \pm 0.03$ \\
\hline
\end{tabular}

receptors in permeabilized hepatocytes, levels of $\operatorname{Ins} P_{3}$ in unstimulated intact cells may be sufficient to ensure that a component of the basal $\mathrm{Ca}^{2+}$ leak from their intracellular stores is mediated by $\operatorname{Ins} P_{3}$ receptors stimulated by $\operatorname{Ins} P_{3}$ [21]. Since the rates of $\mathrm{Ca}^{2+}$ leak were similar whether $\mathrm{Ca}^{2+}$ uptake was inhibited by removal of ATP, addition of thapsigargin, or the combination of thapsigargin and $\mathrm{Ca}^{2+}$ chelation (Table 2), the leak is neither regulated by ATP [22] nor mediated by the $\mathrm{Ca}^{2+}$ pump [23]. The effects of temperature (see below) were consistent with the leak occurring through a channel.

\section{Temperature effects on $\mathrm{Ca}^{2+}$ efflux from intracellular stores}

If, as we suggest, luminal $\mathrm{Ca}^{2+}$ regulates the permeability of the $\mathrm{Ca}^{2+}$ leak pathway, we might have expected the rate constant for $\mathrm{Ca}^{2+}$ efflux to decrease as the $\mathrm{Ca}^{2+}$ content of the stores fell, yet $\mathrm{Ca}^{2+}$ efflux was invariably monoexponential (Figure 1, Table 2). The abrupt closure of the $\mathrm{Ca}^{2+}$ leak would be explained if its regulation operated over a narrow range of luminal $\left[\mathrm{Ca}^{2+}\right]$. In order to slow the fall in luminal $\mathrm{Ca}^{2+}$, and so increase the likelihood of detecting any change in the $\mathrm{Ca}^{2+}$ permeability of the stores as their $\mathrm{Ca}^{2+}$ content fell, efflux experiments were repeated at lower temperatures. Permeabilized cells loaded to steady state with ${ }^{45} \mathrm{Ca}^{2+}$ at $37^{\circ} \mathrm{C}$ were diluted five-fold into CLM at various temperatures in which the free $\left[\mathrm{Ca}^{2+}\right]$ was $\approx 3 \mathrm{nM}$. At $2{ }^{\circ} \mathrm{C}$, ${ }^{45} \mathrm{Ca}^{2+}$ efflux was again monoexponential and even when the incubation was extended to $60 \mathrm{~min}(\approx 7$ half-times $), \mathrm{Ca}^{2+}$ remained within the stores (Table 3$)$. At all temperatures $\left(2-37^{\circ} \mathrm{C}\right)$, the kinetics of ${ }^{45} \mathrm{Ca}^{2+}$ efflux were best fitted by monoexponential equations, although the half-times increased as the temperature decreased. The activation energy $(32.4 \mathrm{~kJ} / \mathrm{mol})$ derived from the Arrhenius plot of the first-order rate constants for ${ }^{45} \mathrm{Ca}^{2+}$ efflux is consistent with $\mathrm{Ca}^{2+}$ leaking through a channel [24]. At all temperatures, the residual $\mathrm{Ca}^{2+}$ content of the stores (calculated by extrapolation of efflux curves collected over a period spanning at least 6 half-times), was similar (Table 3). Even when the fall in luminal $\left[\mathrm{Ca}^{2+}\right]$ was slowed fivefold by reducing the temperature, $\mathrm{Ca}^{2+}$ efflux from the stores terminated abruptly when their $\mathrm{Ca}^{2+}$ content fell to $\approx 0.1 \mathrm{nmol} / 10^{6}$ cells. We suggest that the effects of luminal $\mathrm{Ca}^{2+}$ on the channel through which $\mathrm{Ca}^{2+}$ leaks passively occur within a narrow range of $\left[\mathrm{Ca}^{2+}\right]$.

\section{Conclusions}

We have demonstrated that the passive leak of $\mathrm{Ca}^{2+}$ from the intracellular stores of permeabilized hepatocytes is mediated by neither Ins $P_{3}$ receptors nor the $\mathrm{Ca}^{2+}$ pump; it is not regulated by ATP or cytosolic $\mathrm{Ca}^{2+}$; but it does appear to be mediated by an 


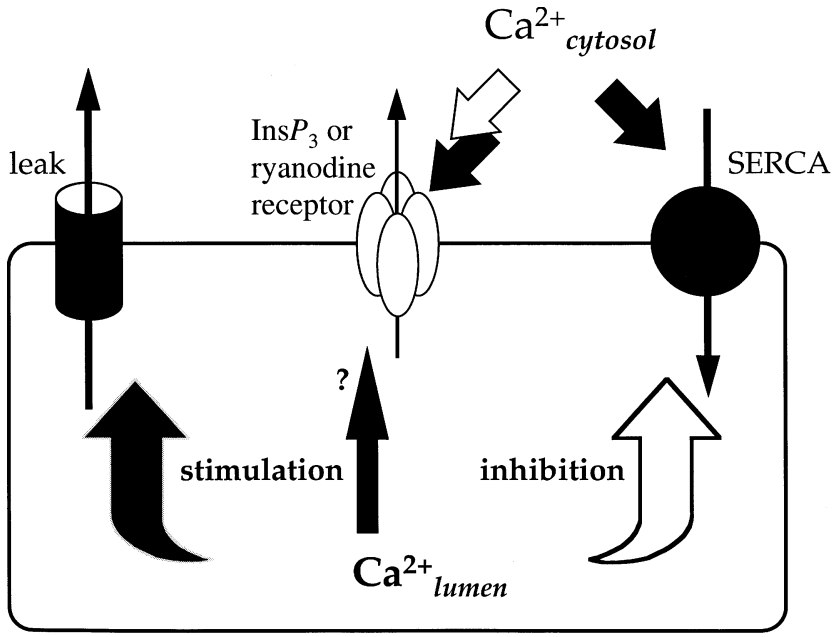

\section{Figure 5 Regulation of the $\mathrm{Ca}^{2+}$ content of the endoplasmic reticulum}

The diagram summarizes results from several cell types to illustrate the many mechanisms that may be involved in regulating the luminal $\left[\mathrm{Ca}^{2+}\right]$ of the intracellular $\mathrm{Ca}^{2+}$ stores, assumed to reside largely within the endoplasmic reticulum [8]. Changes in cytosolic $\left[\mathrm{Ca}^{2+}\right]$ affect the rate of $\mathrm{Ca}^{2+}$ uptake, because most SERCA have $\mathrm{Ca}^{2+}$ affinities similar to the normal cytosolic $\left[\mathrm{Ca}^{2+}\right]$ [8]. Our results suggest that luminal $\left[\mathrm{Ca}^{2+}\right] \mathrm{co-operatively} \mathrm{stimulates} \mathrm{the} \mathrm{channel} \mathrm{through} \mathrm{which}$ $\mathrm{Ca}^{2+}$ passively leaks from the intracellular $\mathrm{Ca}^{2+}$ stores. In other cell types, luminal $\mathrm{Ca}^{2+}$ has also been proposed to inhibit the SERCA in a very co-operative fashion [27]. Finally, ryanodine and $\mathrm{Ins}_{3} P_{3}$ receptors are each sequentially stimulated and inhibited by cytosolic $\mathrm{Ca}^{2+}$ and both may also be stimulated by luminal $\mathrm{Ca}^{2+}$.

ion channel. We [25] and others [6,26] observed previously that a small fraction $(<10 \%)$ of the $\mathrm{Ca}^{2+}$ actively accumulated into intracellular stores by means of the SERCA was not readily released after inhibition of further $\mathrm{Ca}^{2+}$ uptake. We confirmed that observation and now suggest that it results from a steeply co-operative effect of luminal $\mathrm{Ca}^{2+}$ on the leak pathway, such that $\mathrm{Ca}^{2+}$ becomes trapped within the stores when their luminal $\left[\mathrm{Ca}^{2+}\right]$ falls to a critical level (Figure 5). This form of regulation may have important physiological consequences. First, in concert with the effects of cytosolic $\left[\mathrm{Ca}^{2+}\right]$ and the steeply co-operative effects of luminal $\mathrm{Ca}^{2+}$ on the activity of the $\mathrm{Ca}^{2+}$ pump [27], it provides part of a powerful homoeostatic machinery to regulate the $\mathrm{Ca}^{2+}$ content of the endoplasmic reticulum. Such luminal $\mathrm{Ca}^{2+}$ homoeostasis may be important to allow the endoplasmic reticulum and the nuclear envelope with which it is continuous to effectively execute other roles, including protein folding and trafficking, cell growth and nucleo-cytoplasmic transport [9].
Secondly, because a maximally effective concentration of Ins $P_{3}$ empties the $\operatorname{Ins} P_{3}$-sensitive stores more completely than even a very sustained passive leak, the physiological effects of depleting the stores by these different pathways may be different. It has, for example, been suggested $[28,29]$ that the capacitative $\mathrm{Ca}^{2+}$-entry pathway may be activated only after near-complete depletion of the stores and, that in patch-clamped cells, $\operatorname{Ins} P_{3}$ is more effective than thapsigargin in activating capacitative $\mathrm{Ca}^{2+}$ entry [28]. Tight regulation of the luminal $\left[\mathrm{Ca}^{2+}\right]$ of the endoplasmic reticulum by, among other mechanisms, the effect of luminal $\mathrm{Ca}^{2+}$ on the passive leak (Figure 5), may therefore serve both to maintain an appropriate environment within the endoplasmic reticulum and to ensure that capacitative $\mathrm{Ca}^{2+}$ entry is not activated inappropriately.

This work was supported by the Wellcome Trust (039662) and the BBSRC.

\section{REFERENCES}

1 Berridge, M. J. (1993) Nature (London) 361, 315-325

2 Putney, Jr., J. W. (1990) Cell Calcium 11, 611-624

3 Berridge, M. J. (1995) Biochem. J. 312, 1-11

4 Berridge, M. J. (1997) J. Physiol. 499, 291-306

5 Mikoshiba, K. (1997) Curr. Opin. Neurobiol. 7, 339-345

6 Missiaen, L., De Smedt, H., Parys, J. B., Raeymaekers, L., Droogmans, G., Van den Bosch, L. and Casteels, R. (1996) Biochem. J. 317, 849-853

7 Golovina, V. A. and Blaustein, M. P. (1997) Science 275, 1643-1648

8 Pozzan, T., Rizzuto, R., Volpe, P. and Meldolesi, J. (1994) Physiol. Rev. 74, 595-636

9 Meldolesi, J. and Pozzan, T. (1998) Trends Biochem. Sci. 23, 10-14

10 Gaut, J. R. and Hendershot, L. M. (1993) Curr. Opin. Cell Biol. 5, 589-595

11 Short, A. D., Bian, J., Ghosh, T. K., Waldron, R. T., Rybak, S. L. and Gill, D. L. (1993) Proc. Natl. Acad. Sci. U.S.A. 90, 4986-4990

12 Beecroft, M. D. and Taylor, C. W. (1997) Biochem. J. 326, 215-220

13 Nunn, D. L. and Taylor, C. W. (1992) Mol. Pharmacol. 41, 115-119

14 Colquhoun, D. (1971) Lectures in Biostatistics, Clarendon Press, Oxford

15 Sagara, Y. and Inesi, G. (1991) J. Biol. Chem. 266, 13503-13506

16 Fasolato, C., Zottini, M., Clemeti, E., Zacchetti, D., Meldolesi, J. and Pozzan, T. (1991) J. Biol. Chem. 266, 20159-20167

17 Steenbergen, J. M. and Fay, F. S. (1996) J. Biol. Chem. 271, 1821-1824

18 Renard-Rooney, D. C., Hajnóczky, G., Seitz, M. B., Schneider, T. G. and Thomas, A. P. (1993) J. Biol. Chem. 268, 23601-23610

19 Marshall, I. C. B. and Taylor, C. W. (1993) J. Biol. Chem. 268, 13214-13220

20 Taylor, C. W. and Potter, B. V. L. (1990) Biochem. J. 266, 189-194

21 Smith, P. M. and Gallacher, D. V. (1994) Biochem. J. 299, 37-40

22 Hofer, A. M., Curci, S., Machen, T. E. and Schulz, I. (1996) FASEB J. 10, 302-308

23 Du, G. G., Ashley, C. C. and Lea, T. J. (1996) Cell Calcium 20, 355-259

24 Hille, B. (1992) Ionic Channels of Excitable Membranes, Sinauer Associates Inc., Sunderland, MA, U.S.A.

25 Oldershaw, K. A., Nunn, D. L. and Taylor, C. W. (1991) Biochem. J. 278, 705-708

26 van de Put, F. H. M. M., De Pont, J. J. H. H. M. and Willems, P. H. G. M. (1994) J. Biol. Chem. 269, 12438-12443

27 Favre, C. J., Schrenzel, J., Jacquet, J., Lew, D. P. and Krause, K.-H. (1996) J. Biol. Chem. 271, 14925-14930

28 Parekh, A. B., Fleig, A. and Penner, R. (1997) Cell 89, 973-980

29 Hofer, A. M., Fasolato, C. and Pozzan, T. (1998) J. Cell Biol. 140, 325-334

Received 6 May 1998/25 June 1998; accepted 3 July 1998 